\title{
The Standard Language Situation in the Low Countries: Top-Down and Bottom-Up Variations on a Diaglossic Theme
}

\author{
Stefan Grondelaers and Roeland van Hout \\ Radboud Universiteit Nijmegen
}

\begin{abstract}
This paper reviews the available evidence in support of a diaglossic account (Auer 2005, 2011) of the 20th century history of Belgian and Netherlandic Dutch, whereby the national varieties of Dutch are argued to be developing towards a stratificational configuration without discrete intermediate strata between the base dialects and the standard. However, we show that the processes leading to diaglossia differ significantly in the two varieties. While the recent history of Netherlandic Dutch is characterized by downward norm relaxation (top to bottom), Belgian Dutch is characterized by bottom-up (re)standardization. Building on a refined version of Auer's diaglossic model, we reflect on the exact nature of linguistic standardization in the Low Countries and outline scenarios for the further development of Belgian and Netherlandic Dutch.
\end{abstract}

\section{Introduction.}

It is a well-known fact that the national varieties of Dutch-Netherlandic Dutch and Belgian Dutch-are characterized by an uncommonly complex synchronic and diachronic relationship (see Geeraerts et al. 1999, chapter 2 for an overview). Whereas Netherlandic Dutch is in all respects a fully standardized variety, the development of Belgian Dutch was politically hindered in the 16th century, and the predominant idea is that its standardization is as yet unfinished. The rest of the picture, however, is sketchy and incomplete, and until recently it seemed impossible to make reliable predictions about the future of Dutch (as Willemyns 2003 and Van de Velde et al. 2010 state at the end of their overview).

There are three reasons for this. First, it has often been noted that the standard language situation in the Low Countries is so controversial from a linguistic, social, and political point of view that opinions typically prevail over observations. Smakman (2006:8) is sadly right in his 
conclusion that the Dutch standard language has "been subjected more to casual debate than to actual research" (see Geeraerts et al. 1999 and Jaspers 2001:131 for related opinions).

Second, prior to the advent of the Corpus Gesproken Nederlands (Corpus of Spoken Dutch) in 2003, it was virtually impossible to study the relation between Belgian and Netherlandic Dutch in any responsible data-based fashion. The few data-based analyses prior to 2003 were typically limited to one language component and yielded diametrically opposite results. For example, building on a corpus of Belgian and Netherlandic news bulletins from 1935 to 1993, Van de Velde (1996) found evidence for a phonetic divergence between Belgian and Netherlandic Dutch. In contrast, Geeraerts et al. (1999), who investigated diachronic lexical changes in Belgian and Netherlandic Dutch using a corpus of 40,000 content words manually collected from newspapers and magazines from 1950, 1970, and 1990, found progressive lexical convergence between Belgian and Netherlandic Dutch between 1950 and 1990. On the basis of a diachronic corpus drawn from newspapers and Internet logs, Grondelaers et al. (2001) confirmed the convergence in the field of verb-preposition collocations.

However, the low quantity of available language production data is not the only problem. A sizeable proportion of (especially Belgian) research is rooted in a specific language-planning ideology that has affected both the quantity and quality of the data. All the studies cited in the previous paragraph, for instance, are grounded in a methodology that uses the complete standardization of Netherlandic Dutch as a reference point for the standardization process on the Belgian side, which is allegedly unfinished (see above). This approach endangers the description because it assumes a diachronic difference between similar standardization processes, whereas the standardization histories of Belgian and Netherlandic Dutch are, in fact, very different (Jaspers 2001: 142-144). While the history of Netherlandic Dutch is characterized by a spontaneous domestic standardization, Belgian Dutch "imported" Netherlandic Dutch as its standard because language planners of the 19th century believed that the best way to beat the dominance of French - the actual prestige variety in the Belgian territories at the time-would be to adopt the prestige variety of Dutch already available in the North.

This integrationist ideology has dominated language planning as well as language description since the mid 19th century (see section 2 for 
more details). In view of this ideology, any exoglossic borrowing of a completely standardized norm entails that the standardization of the "borrower" is "unfinished" or "delayed." The standardization of Belgian Dutch can only be complete in this sense when full convergence with Netherlandic Dutch is reached. While the latter has been established in the written language - there is one common written norm now in the Low Countries - the late 20th century standardization of spoken Dutch in Belgium clearly goes against the convergence anticipated by the proponents of the dominant integrationist ideology. It is interesting to observe that this endoglossic Belgian development has been condemned and - up to the last decade - almost completely ignored. ${ }^{1}$

In order to steer clear of such ideological bias, we focus as much as possible on actual language data. Recall that these have become available with the advent of the Corpus of Spoken Dutch, and the more advanced use of multivariate statistical analysis has contributed to a better understanding of these data (see especially Plevoets et al. 2007, Plevoets 2009, Van Gijsel et al. 2008, and Zenner et al. 2009).

The third reason for the limited insight into the standard language situation in the Low Countries is that in addition to the shortage of good production data, there is an equally problematic absence of perception data, pertaining to lay evaluations of ongoing change. If, as many contemporary language specialists claim, the Dutch language "is no longer the exclusive property of an elitist upper class of the Dutch population" so that "the norm-imposing establishment is us all" (Bennis 2003), it is essential to find out what untrained members of the speech community think and feel about norm relaxations such as audible regional accents in the standard (see also Smakman 2006:7). When asked explicitly, they would probably pledge allegiance to established norms. Smakman \& Van Bezooijen (1997), for instance, found that the most important standardness criterion for the layperson is the absence of regional flavoring. Attitudinal investigations into implicit, private at-

${ }^{1}$ Jaspers (2001:145) quotes Gal \& Irvine's (1995:974) concept of "deletion" in support of his argument that it is typical for ideologies to ignore or suppress facts that do not fit in with the ideological framework. According to Jaspers 2001 , it is due to such deletion that the emergent Belgian variety of colloquial Dutch has been virtually ignored in linguistic descriptions. 
titudes (Grondelaers et al. 2010, Grondelaers \& Van Hout 2010a,b), however, suggest increasing tolerance for regional elements in the Netherlandic and Dutch standard. In the same respect, Kristiansen (2009) has shown that it is implicit rather than explicit attitudes that reveal ongoing language change processes in modern Danish. At this moment, too few reliable attitudinal data on ongoing changes in Belgian and Netherlandic Dutch are available.

In this paper, we overview the available data on the standard language situation in the Low Countries in order to identify problematic gaps in our knowledge of Standard Dutch, and in order to develop hypotheses about the future of Belgian and Netherlandic Dutch. The structure of this paper is as follows. In the next section, we summarize the (early) sociolinguistic history of the Low Countries that lead to the emergence of the two national varieties. In section 3, we introduce Auer's $(2005,2011)$ typology of European standard-dialect configurations and his own elaboration of the current DIAGLOSSIC constellation in the Low Countries. This representation is corrected and elaborated in the subsequent paragraphs. Section 4 presents the evidence in support of a common written norm. Sections 5 and 6 zoom in on the different dynamics and direction of the standardization processes in the Netherlands and Flanders, respectively, which have led, or are leading to the diaglossic situation presented. In section 7 , the available findings are integrated into a modified version of Auer's original representation. This new representation is then used to substantiate predictions about longterm change.

\section{Short Historical Background.}

Since the linguistic history of Dutch has been extensively reported elsewhere, in this section we limit ourselves to a succinct overview adapted from Geeraerts et al. 1999, Geeraerts 2001a, Willemyns 2003, and Vandenbussche 2010. Historically, Dutch became a standard language in Belgium much later than in the Netherlands. Whereas the Netherlands gained its independence in 1585 (though officially only in 1648), the southern part of the Low Countries remained under foreign rule until the foundation of the Belgium kingdom in 1830. Furthermore, whereas in the Netherlands the development of a prestige variety as part of the newly acquired national identity began in the 17th century, in the southern Dutch-speaking provinces the subsequent Spanish, Austrian, 
and French authorities did not see Dutch as a language suitable for government, culture, and education, and promoted French for these purposes. As a result, around 1800 Dutch was no more than a concatenation of dialects in the southern provinces, inappropriate for supra-regional use. The foundation of the Belgian state in 1830 did not alter this situation much. Since the new kingdom was politically dominated by the French-speaking bourgeoisie, the position of French as the official language became even more firmly entrenched.

In the course of the 19th century, the so-called Flemish Movement started to fight the discrimination of Dutch and speakers of Dutch in Flanders. Willemyns (2003:102) emphasizes the importance of the fact that the first leaders of the Flemish Movement were trained during the short Reunification of Flanders and the Netherlands in 1815-1830. During this period they rediscovered an official variety of Dutch for areas in which it had not been used for two centuries, such as administration, politics, culture, education, etc. These new opportunities opened the eyes of the members of the Movement to the necessity of a supraregional prestige variety of Dutch appropriate for both low and high functions. As far as the actual development of such a variety was concerned, a particularist faction supported the endoglossic standardization of Belgian Dutch, while an integrationist faction advocated taking over the available Netherlandic standard. The integrationist faction eventually won, and up to this day it continues to determine the language-political agenda in Flanders building on ideologies and discourses that were-and still are-language-political as well as socio-political in nature.

It was not until 1898 that Dutch was recognized in Belgium as an official language alongside French, and not until the period between the World Wars that (some sort of) Standard Dutch reached the greater part of the Flemish population and penetrated the lower social strata. However, it was only with the advent of radio and television after World War II and the Flemish viewers' exposure to Netherlandic Dutch in these media that the integrationist program really gained momentum. The Belgian population was actively and consciously encouraged to take over the Netherlandic standard in a number of influential newspapers and TV shows designed to "clean up" Belgian speech and writing. From 1958, the Belgian quality newspaper De Standaard contained a section devoted to taalzuivering 'language purification'. Also, from 1962 to 1972, the Belgian television featured the popular program Hier spreekt men 
Nederlands 'Dutch is spoken here'. Remarkably, these efforts succeeded in providing "almost an entire population in a couple of decades with a more or less new language or, to put it more correctly, with a less known variety of their own language" (Willemyns 2003:111).

The Flemish diffusion of a standard variety of Dutch was sustained by a series of language laws whose main outcome was that after 1930 Dutch became the official language in Flanders. Due to its growing economic success and a series of reforms of the Belgian state, Flanders has developed into a largely autonomous community that has become "of age on the cultural, social, and political level" (Vandenbussche 2010: 311). This coming of age has changed the Flemish underdog attitude into a spirit of self-consciousness towards the French-speaking Belgians and towards the Netherlands.

\section{The Diaglossic Basis.}

In order to qualify and diagram present-day change in the national varieties of Dutch, we make use of Auer's $(2005,2011)$ classification of standard-dialect configurations, which creates synchronic and diachronic order in the heterogeneity of Europe's standard language situations and (de)standardization dynamics. Auer reduces the vast and seemingly disorganized collection of European standard-dialect configurations to a series of five constellations. In applying this typology to Dutch, we adopt Auer's (2011:490) definition of a standard variety, which is based on three features. A standard variety is a COMMON LANGUAGE-ideally, it shows no geographical variation across the territory where it is used; it is an H VARIETY, which has overt prestige and is used in formal situations; and it is a CODIFIED variety, to the extent that "right or wrong plays an important role in the way in which speakers orient towards it" (p. 490; italics in original).

Using Auer's terminology (2011:492-493), the standard-dialect configuration embodied by Belgian Dutch after the first standardization effort (around 1960) would be a TYPE ZERO REPERTOIRE of EXOGLOSSIC DIGLOSSIA. This repertoire has base dialects (represented by the lower ellipsis in figure 1) and an important standard, namely, the Standard Dutch written and spoken in the Netherlands (represented by a single boldfaced dot to convey the absence of variation, especially in the written standard). The Netherlandic standard-dialect constellation, by contrast, would be a TYPE B REPERTOIRE of SPOKEN DIGLOSSIA around 
1960, which involves a written and spoken standard variety developed endoglossically from the dialects; this standard is in a relation of diglossia to these dialects for the following reason:

The structural difference between standard and dialect is perceived as too large to be bridged by intermediate forms. The two varieties are kept apart in speaking, usually because they are subject to different usage norms. Code-switching between standard and dialect is possible but gradual transitions (code-gliding) are not.

(Auer 2011:494)

Standard

Base dialects

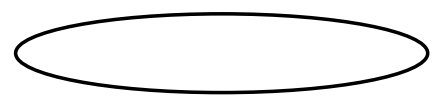

Figure 1. Exoglossic diglossia (Type Zero) in Flanders in 1960.

Figure 2 (below) is a schematic representation of Auer's analysis, where the up-ward arrow represents the endoglossic bottom-up development of the standard out of the base dialects. The small cone under the bold-faced dot represents the spoken standard, which inevitably shows more variation according to Auer (2011:495). The essentially diglossic nature of the Type Zero and Type B repertoires is diagrammed by the absence of contact between the dialect base and the standard.

The claim to be substantiated and elaborated in the following paragraphs is Auer's (2005:22) contention that Belgian and Netherlandic Dutch are evolving into, or have already become DIAGLOSSIC repertoires:

[They are] characterised by intermediate variants between standard and (base) dialect [...], although the implication that we are dealing with a separate variety is not necessarily justified. More usually, the space between base dialect and standard is characterised by non-discrete structures (standard/dialect continuum). 
Standard

Base dialects

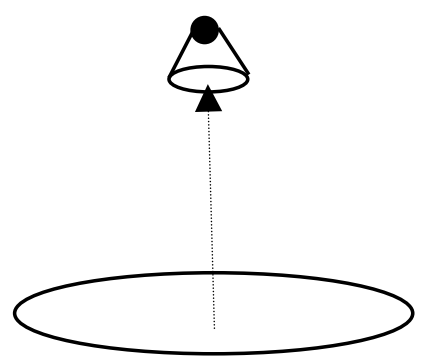

Figure 2. Endoglossic diglossia (Type B) in the Netherlands in 1960.

In the diaglossic configurations in figures 3 and 4 , this absence of discrete strata is represented in non-compartmentalized mono-volumic cones. Diaglossic repertoires come in two types, depending on the vitality of the base dialects: TYPE C REPERTOIRES (figure 3) are characteristic of constellations in which the base dialects are still vital, while TYPE D REPERTOIRES (figure 4)-are constellations in which the dialects are lost (symbolized by the dotted-line ellipsis).

Standard

Regional standards

Regiolects

Base dialects

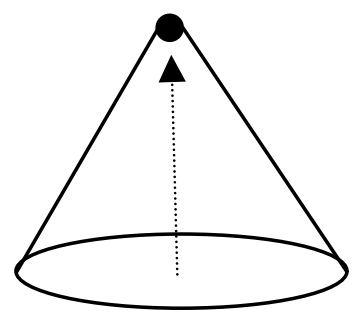

Figure 3. Diaglossia (Type C).

Standard

Regional standards

Regiolects

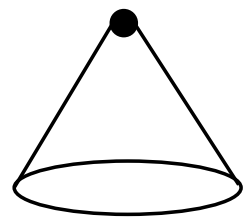

Base dialects

Figure 4. Diaglossia with dialect loss (Type D). 
According to Auer (2005:27), most of Flanders and the Netherlands is Type $\mathrm{C}$ area, whereas "the Randstad area (Amsterdam/The Hague) in the Netherlands, and, somewhat lagging behind, some parts of Flanders, particularly the Brabant, with Brussels and Antwerp spearheading the development" have lost their dialects, and have now become Type D areas. Auer further argues that within the Type $\mathrm{C}$ repertoires, Dutch represents a special case of de- and subsequent re-standardization because of the spoken Belgian Dutch standard which has split off from the Netherlandic standard, "although the codified norm is the same" (p. 25). We have symbolized this split in our use of separate diagrams for the Belgian and Netherlandic configurations.

Although Auer's characterization of the standard language situation in the Low Countries is essentially correct, a number of nuances and elaborations have to be added. First, in its present format the representation pertains exclusively to the relation between spoken Belgian and Netherlandic Dutch; it does not diagram the written standard which is identical in both national varieties (the evidence for the common written norm is presented in section 4). Second, and more importantly, synchronic representations such as figures 1 through 4 represent the endpoint of very different standardization dynamics that cannot be symbolized in these representations. Whereas the Netherlandic configuration is characterized by downward norm extensions (section 5), Belgian Dutch is presently witnessing an endoglossic bottom-up standardization process (section 6).

\section{The Common Written Standard.}

Let us first consider the available evidence in support of the argument that Belgian and Netherlandic Dutch do not have separate written standards. On the anecdotal level, the common written standard manifests itself in the fact that Belgian speakers have no trouble using the 2nd person singular je-pronouns in writing (whereas the $g e$-pronouns are generally used in spontaneous informal spoken communication). While Belgian speakers would generally avoid je-pronouns in spoken conversation (so as not to be mistaken for a "Hollander"), no Belgian of whatever educational or regional background would have any difficulty 
using this pronoun in writing. ${ }^{2}$ In contrast, the use of the ge-pronoun would be much more surprising in formal writing.

The empirical evidence points in the same direction. Building on a corpus of 40,000 terms from the domains of clothing and football and a quantitative measure of lexical overlap, Geeraerts et al. (1999) computed that Belgian and Netherlandic naming preferences strongly overlap in the domains of clothing (81.7\% of all cases) and football $(77.08 \%$ of all cases). On the level of individual lexemes, two Netherlandic clothing terms were never attested in the Belgian materials $(0.73 \%)$, whereas three Belgian clothing terms were never attested in the Netherlandic materials $(2.49 \%)$. In the domain of football, one Netherlandic term was never attested in Belgium (0.17\%), and three Belgian terms were never encountered in the Netherlands (0.64\%; Geeraerts et al. 1999:157-161).

Based on the measure of quantitative overlap used in Geeraerts et al. 1999 and a corpus of verb-preposition collocations (such as zich interesseren voor/aan 'to interest oneself for/at'), Grondelaers et al. (2001) found that prepositional preferences in Belgian and Netherlandic Dutch overlapped in $73 \%$ of cases. It should be noticed in this respect that the list of verb-preposition collocations used in this analysis was based on Penninckx \& Buyse 1997, a normative list that advises (especially Belgian) users of errors to be avoided. The fact that despite the variation-sensitive character of the dependent variable actual usage overlaps in more than $70 \%$ of all cases suggests a common usage and a common norm.

The common norm is also confirmed by the syntactic evidence in Grondelaers 2000, a corpus-based regression analysis of the internal and external factors that determine the distribution of the existential marker $e r$ 'there' in locative inversion constructions. In spite of massive national variation in er's distribution (see also Grondelaers et al. 2008), a comparison between er-preferences in the most formal Belgian quality newspaper De Standaard and the most formal Dutch quality newspaper $N R C$ Handelsblad reveals that the frequency of er-production is identical in these sources, and that it is determined by the same factors.

${ }^{2}$ Except in the West Flemish dialects, where the je-form is endogenous in all phonetic contexts; see Vandekerckhove 2004:988 and 2006:144. 
Recall from section 2 that the common written standard resulted from the Belgian takeover of the Netherlandic norm, which was imposed and promoted by the Belgian intellectual establishment and actively supported by the media. The fact that this language planning endeavor was to a large extent successful in a very short time span is confirmed in Geeraerts et al. 1999 and Geeraerts \& Grondelaers 1997. In these studies, each of the clothing and football lexemes included in Geeraerts et al. 1999 was weighted with a PRO- and an ANTI-factor to reflect the intensity and the frequency with which any given term $x$ was promoted ("use $x$ is instead of $y$ ") or rejected ("please refrain from using $x$ ") in the normative literature published in the 1950's and 1960's. The most important conclusion to be drawn from this investigation is that the postwar convergence of the Belgian and Netherlandic lexicon was due mainly to the decrease of ANTI-terms in Belgian Dutch. Remarkably, there are no substantial increases in PRO-vocabulary during that period, which suggests that the integrationists' efforts have resulted primarily in a rejection of "bad" vocabulary rather than in the acquisition of "good" vocabulary.

\section{The Situation in Netherlandic Dutch.}

It is a generally accepted and uncontroversial fact that in the Netherlands, the written standard is mirrored in a spoken standard used as the everyday language in a wide variety of contexts by all the Dutch (see Smakman 2006:34 and the references cited there). While around the beginning of the 20th century spoken Netherlandic Dutch was still "very much characterized by regionally different features" (Willemyns 2003: 109), the standard that emerged between the world wars was based on the speech of the higher social classes in the Randstad (the urban concatenation of Holland and Utrecht's major cities Rotterdam, Den Haag, Amsterdam, and Utrecht in the west of the Netherlands). ${ }^{3}$ The Western dominance manifests itself in the typically Western pronunciation features - such as the diphthongization of the long vowels /e/ and /o/ and the uvular realization of /g/-previously labeled as substandard but now considered standard, even by speakers who do not use these features themselves (Willemyns 2003:120, note 17).

\footnotetext{
${ }^{3}$ Kloeke (1951) estimated that only 3\% of the Netherlandic population were competent in variation-free spoken Dutch.
} 
Equally uncontroversial is the fact that this spoken standard is currently undergoing changes generally referred to as DESTANDARDIZATION or SUBSTANDARDIZATION. In figure 2, destandardization amounts to a downward relaxation of the standard leading to the emergence of regional and social varieties. In this respect, we discuss three ongoing changes. We focus first on the emergence of regional accents in the spoken standard and then on the rapid dissemination of the notorious Poldernederlands (Polder Dutch) variety. While these two changes represent phonetic relaxations of the spoken standard, the most recent change involves an ongoing syntactic extension. At the end of the section, we challenge and reconsider the idea that these changes constitute destandardization.

As far as the emergence of regional accents is concerned, there is evidence that despite the Western dominance in spoken Netherlandic Standard Dutch, there has always been some tolerance towards (minute) regional flavoring (Smakman 2006:48). In present-day spoken Standard Dutch, however, there is widespread accent variation that goes far beyond the occasional flavoring observed earlier. In 1999, Van Hout et al. compiled the Teacher Corpus, a stratified selection of sociolinguistic interviews with secondary school teachers of Dutch. The purpose of the Teacher Corpus was a "broad registration and detailed inventory of contemporary patterns of variation in standard pronunciation" (Van Hout et al. 1999:184). One of the hypotheses to be investigated on the basis of the Teacher Corpus was subsequently confirmed: "regional pronunciation characteristics are penetrating the speech of Netherlandic Standard speakers, leading to the emergence of regional standard language varieties" (Van Hout et at. 1999:184). Building on data from the Teacher Corpus, Adank et al. (2007) have convincingly shown that the regional background of the speakers can be determined on the basis of vowel formant measurements alone.

While some specialists (notably, Stroop 1998) reject these regional varieties as nonstandard, there appears to be general professional and nonprofessional tolerance toward accent variation in the spoken standard. Especially the layperson's acceptance is important in light of the question whether accent variation is allowed in the standard because it is ontologically impossible to determine standardness based on production 
data alone. ${ }^{4}$ Language is in constant flux, and even among prototypical speakers of standard Dutch there is ample evidence of variation (Smakman 2006). Since one cannot conceive of the standard as a variation-free variety the basic question is how and to what extent the increasing variability is negotiated or constructed in the communal assessment that ultimately determines what is standard and what is not (Grondelaers \& Van Hout 2010:222-223). This amounts to an investigation into STANDARD LANGUAGE IDEOLOGY (SLI; the term was coined by Milroy \& Milroy 1985:23, but see also Silverstein 1979:193). SLI designates a normative ideology imposed by institutions such as (formal) education and the media, but maintained by (silent) agreement among the language users.

In Grondelaers et al. 2009, 2010 and Grondelaers \& Van Hout 2010a, b, we propose a perceptual method to access SLIs. ${ }^{5}$ If, as Woolard (1998:16) claims, language attitudes reflect "socially derived, intellectualized or behavioral ideology," then an investigation into the language attitudes native speakers hold toward regional flavoring in Standard Dutch-as measured in a speaker evaluation experiment-would reveal whether, and to what extent accent variation is accepted as an ingredient of Standard Dutch. More specifically, we propose that a pattern of variability is acceptable as an ingredient of the standard under the following circumstances:

(i) When there is no general downgrading of the norm-deviating variation because it carries useful social meaning: In any society where people have allegiances and identities to maintain (and decode) on the basis of linguistic cues, a regional accent is a valuable cue because it identifies "stable socio-regional groups that are associated with a number of (very) persistent stereotypes" (Grondelaers \& Van Hout 2010:235). A Randstad accent, for instance, is associated with social categories such as "competent," "professional," or "conceited."

\footnotetext{
${ }^{4}$ Willemyns's (2003:110) postulation that "all of this [...] clearly depends on how the standard language is perceived and defined, and what is considered to be its norm; in other words, on the amount and the kind of norm variation one is prepared to accept" is very much in the same spirit.
}

${ }^{5}$ A similar methodology is employed in the work of Kristiansen $(2001,2009)$. 
These social categories are automatically projected onto a speaker about whom one has no prior knowledge. A Limburg accent, by contrast, projects social stereotypes of kindness and lack of sophistication onto an (unknown) speaker (see Preston, to appear for a detailed account of the processing aspects of this attribution).

(ii) When the effect of the norm deviation is limited because the variation is not random or erratic, but normal and predictable: This is the case when the social meanings associated with a variable are known and shared by all the members of the standard language community.

In our perceptual work, both criteria are tested in the speaker evaluation paradigm pioneered in Lambert, Hodgson, Gardner, \& Fillenbaum 1960. In this technique, listeners rate recorded samples of language or accent varieties on a number of evaluative scales. Factor analysis is applied to the resulting corpus of ratings in order to detect the basic dimensions of social meaning. In a first experiment (Grondelaers et al. 2010), a stratified sample of 133 listeners rated short clips extracted from the speech of eight male teachers in the Teacher Corpus (see above). The short clips represented four regional accents of Netherlandic Standard Dutch: the Randstad accent, the peripheral North (Groningen) and South (Limburg) accents, as well as the transitional East (Gelderland) accent.

In compliance with (i), the three identifiable accents (Rand, North, South) evoked stable and invariant social meanings. Unsurprisingly, Western speech from the Randstad accent was consistently regarded as the most prestigious variety, maximally appropriate for formal interaction. Interestingly, the other accents were not systematically rejected. While Southern-sounding speakers were downgraded in terms of prestige, they were upgraded in terms of personal integrity, and their speech was rated as the most beautiful of the investigated varieties. It was also awarded a higher norm status than any of the other investigated accents except the Randstad accent. Crucially, there was no demographic bias in the ratings, which means that the social meanings observed are national constructs, shared by all the Dutch (as stipulated in ii). Therefore, the provisional conclusion to be drawn from this perceptual evidence is that identifiable accent variation is a meaningful ingredient of Netherlandic Standard Dutch in the layperson's mind. 
The question is, however, how can one be sure that the social meanings attested are not restricted to a neutral speech context in which a regional accent is not sanctioned in any way? In a follow-up experiment (Grondelaers \& Van Hout 2010), the speech of six teachers representing the Randstad, North, and South accents was presented to the listeners in a professional guise (in which speakers repeatedly referred to the teaching profession) and in a neutral guise (in which there were no references to any profession). In light of the discussion so far, one could hypothesize that irrespective of their specific accent, the speakers are not downgraded in their neutral guise, but they are all rejected in their teacher guise because teachers of Dutch are not supposed to have an accent. Yet, the social meanings revealed by the ratings turned out to be accent-driven rather than profession driven: Whether or not the speakers revealed themselves as teachers played only a moderate role in how their speech was perceived by the listeners. What matters, therefore, is not whether teachers have an accent, but which accent they have. In combination with the fact that no demographic bias was found in the ratings, these findings confirm conclusively that regional accent variation has become an inalienable ingredient of spoken Netherlandic Standard Dutch. ${ }^{6}$

The second ongoing change in Dutch to be discussed here - the emergence of so-called Poldernederlands "Polder Dutch"-is much more controversial than the regional accents: the linguist who first observed the change (Stroop 1998) regarded it as a sign of the imminent demise of

${ }^{6}$ Another interesting barometer for the extent to which accent variation is accepted in Netherlandic Standard Dutch is radio language policy. Following Milroy \& Milroy 1985, Van de Velde et al. (1997:363) argue that there is "a fascinating continual interplay between radio language on the national broadcasting stations and standard language, in which the audience defines the standard (Milroy \& Milroy 1985). Broadcasters accommodate toward the standard, but it does not imply that their usage coincides exactly with the abstract standard. Small deviations of the standard will show up. If according to the listeners-who consider the speech of broadcasters as representative of the standard - these deviations fall outside the range of variation tolerated within the standard, they will react to it (...)." If Van de Velde's hypothesis is correct, the fact that a non-regional pronunciation is no longer a prerequisite for Dutch radio presenters (Smakman 2006:48) testifies to the general acceptance of regional accents in Netherlandic Standard Dutch. 
the standard language - the variety he still refers to as Algemeen Beschaafd Nederlands 'Common civilized Dutch', while most linguists now use the term Standard Dutch (see the discussion in Smakman 2006:33ff.). Stroop observed that educated middle class females lowered the pronunciation of the first element of the /ei/-diphthong, and as a result the diphthong sounded as [a:i]. For example, a word such as plein 'square' is realized as [pla:in]. The same type of change, however, appears to have affected the diphthongs /ui/ and /au/ as well (Stroop 1998:25-26). Owing to its pioneers - avant-garde females, presenters on the MTV-like pop channel TMF, and hosts in semi-intellectual talk shows-Poldernederlands is claimed to be surrounded by a "realm of intellectualism, commercialism, and pop culture" (Smakman 2006:50).

While Smakman (2006:50) raised the legitimate question whether this Poldernederlands really is a new variety, Van Bezooijen (2001) conducted a speaker evaluation experiment in which linguistically untrained native speakers evaluated different unlabelled varieties of Dutch. Van Bezooijen found that for linguistically naive female native speakers, Poldernederlands is a separate variety "with an individual status" (p. 268), and that especially younger females have a more positive attitude towards Poldernederlands than toward the other investigated varieties (among which nonaccented Standard Dutch, p. 269). In other words, there is evidence for the subconscious acceptance of Poldernederlands, and Van Bezooijen anticipates "a somber future for Standard Dutch but a bright future for Poldernederlands" (p. 269). This "rosy future" has in the meantime been confirmed on the level of production. While the use of Poldernederlands was initially restricted (or thought to be restricted) to educated middle class females, Jacobi (2008) reported evidence that the phonetic lowering of the onset of some diphthongs has spread to educated male standard speakers as well.

The third and most drastic change pertains not to the pronunciation of spoken Standard Dutch but to its morphosyntactic core. Since the beginning of the 1990's, linguists and nonlinguists have been aware of the rapid spread of the object form hun of the 3rd person personal pronoun in subject position, as in Als je zo speelt krijgen hun natuurlijk altijd kansen 'If you will play like that them will always get chances' (Van Hout 2003:277). In contrast with the norm deviations discussed in the previous paragraphs, this change excites (extreme) irritation on the part of teachers and language purifiers (see, for instance, the quotes in 
Van Hout 2006:42, as well as the normative comments on the website of Onze Taal, http://www.onzetaal.nl/advies/ hunhebben.php). According to Van Hout 2006:42, a recurrent reason for this irritation is that the erroneous use of hun is thought to "spring from ignorance or worse still, from stupidity. The rule is so evident: use $z i j$ or $z e$ for the subject."

However, Van Hout argues convincingly that the use of hun as an emphasized subject pronoun follows a system-internal logic because it reduces the massive double duty inherent in the current pronoun system (in which a great number of pronouns perform a dual function). Likewise, Van Bergen et al. (2011) suggest that hun is functionally superior to the standard pronoun $z i j$ 'they' because it denotes exclusively animate entities, whereas $z i j$ is intrinsically ambiguous between animate and nonanimate referents. Given this system-internal superiority, it is also logical that subject-hun occurs early in child language (Van Hout 2006). In addition, there is evidence that hun is also rapidly spreading in the dialects, and that it marks the language of famous Dutch football players, which lends the phenomenon covert prestige. Therefore, it is predicted that "hun will eventually win out in Standard Dutch" (Van Hout 2006:285) in spite of extremely negative explicit attitudes towards it.

Unfortunately, there is no speaker evaluation evidence yet to determine listener attitudes toward subject-hun. However, given the rate at which the pronoun is spreading and the scope of this development-in the meantime, subject-hun has penetrated the Southern dialects-it would likely become subconsciously accepted soon after it penetrates all the strata of Netherlandic Dutch. Its eventual acceptance, however, would not be due to its socio-semantic richness (as in the case of regional accent variation) or because of its overt prestige for "cool people" (as in the case of Poldernederlands). Nor do we believe that the rapid diffusion of subject-hun can be explained solely by recourse to the system-internal optimization it effects (though that is probably the reason why once initialized, it has spread so fast). If anything, we speculate that it is system-internal efficiency in combination with a certain covert prestige inherent in the anti-authoritarian challenge of a conservative ideology that is crumbling rapidly. ${ }^{7}$

${ }^{7}$ Grondelaers \& Van Hout (to appear) describe the change from a conservative to a more liberal SLI not only on the basis of the available speaker evaluation data, but also on the basis of a content analysis of viewer reactions to the (by 
At the end of this section, two related questions remain to be addressed. First, is Netherlandic Dutch anno 2011 a diaglossic Type C repertoire or a dialectless Type D configuration? Second, is the downward norm relaxation really indicative of destandardization, to the extent that new varieties are emerging outside the codified norms of original spoken Standard Dutch?

As far as the first question is concerned, we believe that the current evolution in Netherlandic Dutch is more indicative of a dialect loss repertoire than a diaglossic repertoire. Massive dialect loss in the Netherlands has been reported in Willemyns 1997, 2003, 2007, Vandekerckhove 2009, Smakman 2006, and Hinskens 2007, although the southern province of Limburg seems to be resisting the trend somewhat. The impact of dialect loss in the Low Countries extends beyond the demise of local repertoires, however, and this brings us to the second question.

According to Willemyns (2007:270-271), dialect loss in the Netherlands and Flanders conditions the relation between the higher layers in the continuum by necessitating an informal variety (in between the disappearing dialects and the standard) that indexes regional identity. Given the smaller distance between this intermediate variety and the standard, "many people see no inconvenience in using the former in situations where actually the use of the latter would be more appropriate" (p. 271). Although he does not actually refer to the newly adjoining layers - informal spoken Dutch with regional standard variation and the uniform standard-as one stratum, his claim (in the identical context) that "people are gradually restricting their choice of possible varieties to just one single variety, modified only slightly according to different communicative situations" (p. 271) is strongly suggestive of a monostratal conception.

Auer (2011:500) reasons along related lines, but he reverses the causality by claiming that it is changes at the standard end of the configuration that weaken the traditional dialects:

now notorious) televised debate between Helen de Hoop and Ronald Plasterk on possible "solutions" to the rapid proliferation of subject-hun. 
[S]peakers develop intermediate forms, which results in the emergence of new ways of speaking that avoid the negative social prestige now attached to the dialects but nonetheless display regional identity (i.e. a diaglossic repertoire emerges).

In a more advanced situation still, Auer (2011:501-502) claims that this development engenders a multi-stylistic standard variety which is DEMOTICIZED (Mattheier 1997), namely, it is extended from a spoken version of the written standard to a variety suitable for spoken, face-toface interaction, also between less educated speakers. Demoticization emerges in response to the fact that "many speakers no longer have a dialectal way of speaking at their disposal. Therefore, the standard has to be able to provide the full range of expressive resources the speakers need" (Auer 2011:500).

The latter, we claim, is basically what has happened in Netherlandic Dutch: The disappearance of the dialects has put pressure on the standard to relax its norms and include variation for purposes of regional and social stratification. So, instead of engendering the emergence of substandard varieties outside the norm, the standard has stratified to become an indicator of the speaker's regional origin (note the perceptual acceptance of regional flavoring in the standard) and of the speaker's social profile (note the progressing acceptance of the Poldernetherlandic lowering of some diphthongs). To what extent the desire to abandon the low prestige associated with the dialects has co-determined this development is unclear. In any case, this development resulted in a downward relaxation of norms, which, in turn, has led to the present-day situation.

\section{The Situation in Belgian Dutch.}

In Belgian Dutch, the written standard is mirrored in a spoken variety which is commonly referred to as VRT-Dutch because of the central role the Vlaamse Radio en Televisie 'The Flemish Radio and Television' has played in its propagation and diffusion (see Van de Velde et al. 1997 and Vandenbussche 2010 for a more extensive account). Since its foundation in 1930, the VRT has been a major proponent of the integrationist ideology by actively promoting a variety of Standard Dutch modeled 
after spoken Netherlandic Dutch. ${ }^{8}$ According to Marc Galle, professor of linguistics and pioneer of media-supported language planning, "it was our conviction that we rapidly needed to attain a tighter language union with the Netherlands without sacrificing the variation beforehand" (quoted in Vandenbussche 2010:312-313, italics ours-SG \& RvH).

From the beginning, the VRT has imposed the strictest possible norms on the language use of its radio and television hosts by requiring them to adhere to the most authoritative pronunciation guide (Vandenbussche 2010:312). All potential hosts still have to pass a rigorous pronunciation test, and they are continuously subjected to strict internal controls. Until recently, candidates have been rejected on the basis of the slightest regionalism in their pronunciation. The result of these standardization efforts is a "rather formal spoken variety which is certainly more uniform than the spoken standard norm for Netherlandic Dutch" (Beheydt 2003:160; recall from the previous section that a neutral pronunciation without regional flavor is no longer required from Dutch radio speakers, see also Vandenbussche 2010:312).

On a more critical note, De Caluwe (2009:19) refers to VRT-Dutch as a "virtual colloquial variety (...), desired by the authorities, but rarely spoken in practice." In practical reality, VRT-pronunciation represents an almost unattainable ideal achieved by only a small minority of Dutchspeaking Belgians in a limited number of contexts (see, amongst many others, Goossens 2000:8, Geeraerts \& De Sutter 2003:57, and Beheydt 2003:160). ${ }^{9}$

${ }^{8}$ Although VRT-Dutch was modelled after the most formal Netherlandic Dutch, its pronunciation is audibly different (Geeraerts \& De Sutter 2003:55), especially because long vowels are not diphthongized (as is typically the case in most varieties of spoken Netherlandic Dutch), and the voiced fricatives [g], [v], and $[\mathrm{z}]$ remain voiced (whereas they are frequently devoiced in Netherlandic Dutch).

${ }^{9}$ It is revealing in this respect that as soon as they leave their radio studio, many VRT-presenters "lower" their standard, even to the level of Tussentaal (see below). Having been a freelance music critic for the national radio for the past decade, Grondelaers has noticed that this lowering occurs progressively more often, especially in the speech of younger presenters. Although we have been unable to find any printed evidence to that effect, we have the impression that the strict VRT-standards are being relaxed somewhat in recent years. This is, no 
The highest nonvirtual stratum of Belgian Dutch is documented by the speech of the Belgian teachers in the Teacher Corpus (see above). Note that these teachers proclaim themselves guardians of the standard language (Van de Velde \& Houtermans 1999), who are loyal to official pronunciation norms (De Schutter 1980). Moreover, they all knew in advance that their speech would be recorded for inclusion in a corpus of standard Dutch. Nonetheless, the speech of only a few of them approximates the strictest VRT-norm. The majority of speakers in the Belgian Teacher Corpus has a regional accent that can be easily identified by Belgian listeners with no linguistic background. In an evaluation experiment, the speech of Belgian teachers from the Teacher Corpus was used as a stimulus (Grondelaers et al. 2009, see below). Even though the teachers were not selected on the basis of the strength of their regional accent, the regional origin of five out of six speakers from the major accent zones was correctly identified by $70 \%$ of the listeners. ${ }^{10}$ In addition to a regional accent, a sizeable proportion of the teachers in the corpus manifest substandard features in their speech, such as $t$-deletion in function words.

What all the speakers in the Teacher Corpus have in common, however, is their natural use of elements inherited from the common Belgian/Netherlandic written standard and the Dutch spoken standard (such as the je/jij-pronouns, see above). In spite of this adherence to the standard, the teachers' formal spoken Dutch as illustrated in the Teacher Corpus is not a uniform variety. Recall, however, that this does not necessarily mean that the teachers' Dutch is also perceived as nonstandard by the layperson. The variation observed does not endanger the status and function of Belgian Standard Dutch when it is not syste-

doubt, due to the advent of commercial television in Belgium that has not only introduced television language "without a normative role" (Jan Schoukens, language advisor for the commercial network VTM, in Permentier 2003), but which thrives on "stars who will not accept that a language advisor corrects their pronunciation."

${ }^{10}$ The regional identification of two speakers from the transitional accent zoneEast Flanders - was more problematic (it was identified correctly by $44.09 \%$ and $29.67 \%$ of the listeners), and one West Flemish speaker was mistaken for an East Fleming. 
matically rejected, and when it generates useful social meanings shared by all the members of the Belgian standard language community.

In order to answer the question how speakers of Belgian Dutch rate Teacher Dutch, the experiment reported in Grondelaers et al. 2010 was replicated in Grondelaers et al. 2009 using Belgian speech samples and Belgian participants. We extracted sample clips from the speech of eight speakers, who represented four accent regions: the central zone (the Brabant-Antwerp axis, the nation's socio-economic hub), two peripheral zones (West Flanders and Limburg, rural areas in which the base dialects are still frequently spoken), as well as a transitional zone (East Flanders). Except for the latter, these zones feature well-identifiable regional accents. One hundred native speakers of Belgian Dutch from the four accent regions included in the experiment were selected as listeners.

While we found no general downgrading of accented speech in our Belgian data, we observed clear differences between the social meanings obtained in this experiment and in its Netherlandic counterpart (despite the fact that the scale set on which accents were evaluated was very similar in the two experiments). In contrast to Netherlandic Dutch, the attractiveness of the accents and their speakers appeared to play (almost) no role in the perception of Belgian teachers' Dutch. Neither was the central Brabantic accent-or any other accent-found to be more "appropriate" for formal interaction (recall that in Netherlandic Dutch, the formal status of the Randstad accent was confirmed repeatedly). Furthermore, it was found that the central Brabantic accent was not the only prestigious variety: An (unintuitive) binary distinction was found between the prestigious accents of the central (Brabantic) and transitional (East Flemish) zones on the one hand, and the non-prestigious accents of the peripheral Limburg and West Flemish zones on the other hand.

While only "old" status indicators emerged from the perceptual analysis of the Netherlandic Dutch accent variation (associated with "established" prestige such as good education, professional competence, good manners, etc.), the analysis of the Belgian Dutch accents revealed, in addition, ratings which correlated into the "new" status dimension of DYNAMISM defined in terms of rhetorical skills and media suitability. Kristiansen (2009) gauges the current rise in prestige of "Lower" Copenhagen speech in terms of such Dynamism, which, in his view, characterizes standards for the media rather than for the schools 
(Kristiansen 2001). As far as the Belgian accents are concerned, it is the Brabantic and East Flemish accents which are deemed the more Dynamic.

However, the most important difference in the perception of the Belgian and the Netherlandic accents is the following: While the perception of the Netherlandic accents is clearly a national construct, to the extent that perceptions are shared by all the speakers of Netherlandic Dutch, we found massive demographic bias in the perception of the Belgian accents. The most evident is the significant variation among the listeners' home regions, and this variation affected approximately half of the overall ratings. This indicates that the most formal variety of spoken Belgian Dutch available in actual practice does not elicit national perceptions shared by all the speakers of Belgian Dutch: Belgian listeners evaluate the samples as Limburgians, Brabantians, Antwerpians, and East and West Flemings (instead of Dutch-speaking Belgians), manifesting all the concomitant in- and out-group biases.

Although the perceptual picture is still far from being complete, the available data raise the pertinent question to what extent teachers' Dutch is standard Dutch. If there is a standard variety of Belgian Dutch, it is in any case losing ground to the variety of colloquial Belgian Dutch neutrally referred to as Tussentaal (which literally means 'in-between language' because it is a more or less autonomous variant between the standard and the dialects). Dysphemistically, however, it is dubbed Soapvlaams (because it is a speech variety typically used in soap operas, Geeraerts 1999), Schoon Vlaams (literally, though ironically, 'beautiful Flemish', Goosens 2000), or Verkavelingsvlaams ('allotment Flemish', Van Istendael 1989). ${ }^{11}$ Van Istendael (1989:108-109) suggests that Tussentaal is "the language of a novel, Flemish self-consciousness which is false to the core, it is a language which springs from fear for the dialect and fear for Dutch, it is a monster, this language of Flemish intellectual laziness." ${ }^{2}$

${ }^{11}$ In Flanders, an allotment is a stretch of (former farm) land partitioned into building lots. According to Van Istendael 1989, Verkavelingsvlaams is the variety of Dutch allegedly spoken by the nouveau riche who typically inhabit allotments.

${ }^{12}$ De Caluwe (2002:58-60) contains an overview of attitudes against Tussentaal. 
Although Tussentaal is immediately recognizable to Belgian listeners, it cannot easily be characterized in terms of necessary and sufficient features. Nevertheless, Goossens (2000:9-11), De Caluwe (2002:57-58), Geeraerts \& De Sutter (2003:57-60), and Plevoets et al. (2007:180-182) provide a list of defining phonological and lexical features, while Goossens (2000) provides a list of defining morphosyntactic features of Dutch. According to Taeldeman (2007), the defining characteristics of Tussentaal are dialectal elements, not typical for one region, which have a low symbolic value for specific regions as "carriers" of linguistic identity. As a result, such elements can indicate a supra-regional variety. Building on the statistical analysis of 80 variables in stylistically different subcorpora of the Corpus of Spoken Dutch, Plevoets et al. (2007) argue that Tussentaal is not a uniform language variety (a different quantitative analysis in Plevoets 2009 confirms this conclusion).

Yet, there appears to be a growing influx in Tussentaal of features from the central Brabant-Antwerp axis. Building on an investigation of two morphosyntactic variables in a teenage chat room - a form of highly informal internet communication that uses a supra-regional variety since chat participants come from different Flemish regions-Vandekerckhove $(2006,2007)$ found a marked preference for colloquial variants which are key elements in the Brabantic repertoire. De Caluwe (2009:8), likewise, suggests that although Tussentaal is not a uniform variety yet, it is Brabant-flavored Tussentaal that manifests "the highest status and widest distribution." In view of this growing dominance of Brabant-colored Tussentaal in supra-regional communication, Willemyns (2005:30; cited in De Caluwe 2009:17) suggests that Verkavelingsbrabants 'Allotment Brabantic' would be a more adequate denomination for Tussentaal.

There is general agreement among all observers from various ideological backgrounds that the rapid spread of Tussentaal represents a case of "autonomous informal language standardization" (Cajot 1999: 375 ), although this view is rarely found in print yet (see, however, Vandekerckhove 2007:202, who suggests that the massive use of Tussentaal in a "public written medium with a wide communicative reach [an internet chat channel which serves Belgian users of various regional backgrounds, $\mathrm{SG} \& \mathrm{RvH}]$ may well be symptomatic of an autonomous Flemish standardization process taking place right now").

The paucity of documented evidence for the endoglossic standardization that Belgian Dutch is currently undergoing reflects the cultural 
establishment's unease and panic with respect to a development running counter to the adoption of the exoglossic Netherlandic standard proposed and promoted by integrationist language planners (see Jaspers 2001:131; the large number of dysphemistic terms for Tussentaal cited above is also suggestive of this unease). This integrationist rejection of Tussentaal has had profound consequences for our understanding of present-day Belgian Dutch because prior to 2005, "Tussentaal was not analyzed but merely incurred disapproval" (Jaspers 2001:131, but see also De Caluwe 2009). ${ }^{13}$

With the advent of the Corpus of Spoken Dutch and the wider availability of statistical software to perform multivariate analysis, a body of quantitative evidence has emerged that can be used to confirm or refute some of the claims and complaints about Tussentaal recurring in the integrationist literature. These claims are listed in 1 through 5, while 6 and 7 elaborate on two factors (attested in ideologically neutral accounts), which are claimed to have caused the emergence of Tussentaal:

(1) Tussentaal is a transitional variety on the way to becoming a fullyfledged spoken Belgian standard, and as such it represents the provisional endpoint of the spontaneous standardization of a spoken variety of Belgian Dutch. The most explicit embodiment of this expectation is Hendrickx's (1998) claim (cited in Vandenbussche 2010:318):

We are convinced that with the further spread of the use of Standard Dutch in Flanders, this Tussentaal will disappear even more in its current form. It will be replaced by an informal variant of the standard

${ }^{13}$ Dirk Geeraerts is one of the rare protagonists of the integrationist ideology whose strong dislike of Tussentaal did not stop him from studying it in addition to condemning it. While Geeraerts et al. 1999 was one of the first quantitative studies to include a typical Tussentaal register, Grondelaers et al. 2001 investigated lexical preferences in Belgian and Netherlandic chat channels (chat being a "hotbed" for Tussentaal, see above). Plevoets et al. 2007, Van Gijsel et al. 2008, and Zenner et al. 2009 are multivariate corpus-based studies of Tussentaal. 
language which relates in a natural and close way to the standard variety that is already accepted in Flanders in the formal register.

(2) While Tussentaal represents the best variety of spoken Dutch for uneducated Flemings, who are unable to acquire the exoglossic standard, it is also increasingly spoken by people who are sufficiently educated to acquire the exoglossic standard. This state of affairs raises concern with respect to claim 1 (Taeldeman 1993 was the first to observe this).

(3) Tussentaal represents a 'norm degradation' ("normverlaging," Taeldeman 1993:13) and even 'norm falsification' ("normvervalsing," Taeldeman 1993:13), which is "consciously" (Taeldeman 1993:13) effected by a large proportion of the Flemish "elite" (Taeldeman 1993:13; quotation marks in the original) guilty of "cheap arrivisme and opportunism" ("goedkoop arrivisme/opportunisme," Taeldeman 1993:13). The use of Tussentaal in situations that call for a standard variety is caused by a "diminished sense of public responsibility" ("tanende burgerzin," Geeraerts 1993:352) of a type of Fleming who is "amoral in his compromising pragmatism" ("amoreel in zijn schipperende pragmatisme," Geeraerts 1990:439-440).

(4) Tussentaal is a completely superfluous variety in the availability of "natural" varieties such as the dialects and prestige varieties such as the standard. Tussentaal is unnatural, culturally inferior, and it has low prestige and a total absence of cultural prestige products (see for instance Goossens 2000).

(5) Tussentaal has been engendered by the increasing Flemish political independence and economic success, which has changed former feelings of inferiority into attitudes of self-consciousness and superiority with respect to (especially) French-speaking Belgians, but also with respect to the Netherlandic neighbors.

(6) The increasing informalization and democratization of our society enhance the linguistic norm relaxation that characterizes contemporary Belgian and Netherlandic Dutch (Kristiansen (2009) follows Giddens (1991) in his use of the term Late Modernism to 
refer to the current era of globalism and democratization; compare also Jaspers 2001:132-133, Goossens 2000:5, Stroop 1998:227, Geeraerts 1993:352; Vandenbussche (2008:190) refers in this respect to the post-1968 era as the period of the definitive crisis of a culture that was bourgeois to its core).

(7) According to Willemyns (2007, but also compare Vandekerckhove 2009:91-93), it is the loss of the Belgian dialects which is the prime determinant of the widespread Flemish preference for Tussentaal. In fact, Willemyns (2007:270-271) proposes the same explanation for the emergence of Tussentaal as for the birth of Poldernederlands in the Netherlands (see above): The demise of the dialects necessitated an informal colloquial variety that indexed regional identity. This intermediate variety was subsequently used in more situations and domains than before, taking over the functions of the standard variety. This leads to the following situation:

Standard language is pushed to the extreme formality side of the continuum, whereas, simultaneously, the use of the dialects is constantly diminishing. Together, these two developments are responsible for the creation of an enormous amount of space on the continuum scale. That is, the intermediate variety now occupies a huge field, and has the possibility to move either to the left or the right according to the circumstances, thus alternatively taking the shape of a more dialectical or a more standard-like intermediate variety.

(Willemyns 2007:270)

Each of these claims can be evaluated in the light of the available evidence (in particular, the more recent quantitative data). With respect to claim 1, it is obvious to anyone living in present-day Flanders that Hendrickx's (1998) prediction of the emergence of a colloquial variety of Belgian Dutch which would closely reflect the formal standard has not come through: "9 years onwards, Tussentaal still appears to be on the rise in Flanders and no major shift towards the informal VRT-variant has been reported, so far" (Vandenbussche 2010:318).

One of the reasons for the success of Tussentaal is the correctness of the integrationist concern voiced in claim 2 . In an attempt to learn more about the social determinants of Tussentaal use-beyond education 
(claim 1) and social (middle) class affluence (claim 2) -Plevoets (2010) computed the linguistic distance between genders, professional categories, degrees of education, and age on the basis of 37 Tussentaal variables attested in the Corpus of Spoken Dutch. Plevoets found that the cultural elite-academics, media professionals, and artists-in general prefer standard variants, whereas the economic elite-managers and other highly educated professionals - are more inclined to use Tussentaal. In addition, there is an effect of education: Highly educated professionals have a tendency to use Standard Dutch, except, crucially, highly educated managers, who unmistakably prefer Tussentaal. Plevoets also found an age effect: While the cultural elite holds on to Standard Dutch longer than the economic elite, the youngest generation-from 1970 onward-exhibits a general preference for Tussentaal in all professional groups. Finally, as far as gender is concerned, female speakers-who, according to conventional sociolinguistic wisdom, are more prestigesensitive-manifest a significantly higher preference for Tussentaal.

In compliance with the generation effect found in Plevoets 2010, other recent data confirm that young speakers no longer appear to have any reservations about using Tussentaal instead of Standard Dutch. De Caluwe (2009) found a strong preference for Tussentaal in the CGNrecorded colloquial speech of young adults between 18 and 24 (except in West Flanders, where the dialects still have a strong presence, and where Brabant-flavored Tussentaal is as much a foreign variety as Standard Dutch). However, the other provinces manifest a Tussentaal proportion of more than $50 \%$ on four morphosyntactic variables. In convergence with these production data, Van Gijsel et al. (2008:217-220) carried out a regression analysis to investigate the contextual and situational determinants of the use of Tussentaal in a corpus of radio and television commercials. They found that Tussentaal was used significantly more frequently in radio commercials, in the (typically lively) mini-drama component of a commercial, and in commercials geared toward an adolescent audience.

In combination with the fact that many linguists detect stabilizing and uniforming tendencies in Tussentaal (Cajot 1999, Goossens 2000, Taeldeman 2007), the preference for Tussentaal in the best educated circles of the leading classes (who have the means to acquire Standard Dutch if they wish to) and the growing general preference for Tussentaal among young people suggest that Belgian Dutch is undergoing an 
endoglossic bottom-up standardization, which is turning it from a Type Zero into a Type $\mathrm{C}$ or Type $\mathrm{D}$ repertoire (depending on whether the dialects in Flanders are considered completely lost).

Even if it is true that the Flemish dialects are disappearing, Willemyn's (2007) claim - repeated as claim 7 above - that dialect loss has conditioned the present-day Tussentaal situation in Flanders is, in our view, an exaggeration. While the demise of the dialects in the Netherlands put pressure on the Netherlandic standard to stratify, dialect loss in Flanders plausibly accounts for the emergence of Tussentaal to replace the lost dialects. Yet, this does not explain why the new intermediate variety is penetrating the contexts in which Standard Dutch is typically spoken, and why it is acquiring prestige. Neither can democratization and globalization-claim 6-be the only reason for Tussentaal to spread and standardize at this rate.

We propose that in Flanders, the post-1968 feelings of antiauthoritarian resentment that triggered destandardization in many European languages (Deumert \& Vandenbussche 2003) were intensified by the "foreignness" of the exoglossic norm imposed on ordinary speakers, as well as by the condescendence of the integrationist ideology and discourses. The spoken norm imported from the Netherlands has never been a familiar or comfortable medium with which Flemish users feel at home. As a result, Belgian speakers consider the standard variety "as a foreign variety appropriate for formal interaction but to be dropped as soon as the situation no longer demands it" (De Caluwe 2002:61). In the same vein, Geeraerts $(1999,2001 b)$ and Taeldeman (2007) have referred to the standard as a "Sunday suit," an indispensable piece of clothing which one takes off, however, as soon as the occasion no longer demands it.

In addition, the VRT-variety of Standard Dutch has been imposed on the community from above (Jaspers 2001, De Caluwe 2009) in an intellectual climate hostile to variation and language planning efforts that all too often coincided with a crusade against endogenous Flemish varieties such as the dialects (see Taeldeman 1993:15). The repression inherent in the integrationist enterprise can be inferred from the dysphemistic labels for Tussentaal (see above), the moral condemnation of people who prefer Tussentaal although they are competent in Standard Dutch (claim 3), and from the data in Geeraerts \& Grondelaers 1997 that demonstrate that 20th century language planning in Flanders has led, in 
particular, to a rejection of stigmatized words the purists disapproved off, not to a more frequent use of approved terms.

In addition, and crucially, the emergence of a new Flemish selfconsciousness and the birth of a Flemish nation state have increased the speakers' desire for a Flemish standard. At the same time, it decreased the need for (and the success of) integrationist language policies and ideologies. This decrease was accelerated by the advent of commercial television in Flanders: Ever since commercial alternatives to national television have become available, the Netherlandic television responsible for a major influx of standard vocabulary in the speech of Belgian adolescents (Goossens 2000) is no longer the preferred alternative to Belgian state television in Flanders.

It is interesting to notice that the endoglossic Flemish standardization process has almost nothing in common with standardization processes in other European countries. In a study that investigates standardization factors based on 16 Germanic standard languages, Vandenbussche (2007: 26) observes that "similar factors have influenced the process of language change and similar discourse strategies have been used to defend or fight certain standardization decisions." Vandenbussche (2007: 28-30) then goes on to discuss prototypical "standardizers," namely, "recurring core elements which have had a serious impact on the standardization of the different Germanic languages" (p. 28). Interestingly, almost all of these standardizers have until recently opposed and suppressed the ongoing endoglossic standardization of Tussentaal (though some change is noticeable). Printers have never questioned the written standard of Dutch, and schools are one of the few remaining enforcers of the exoglossic norm (see Grondelaers \& Van Hout 2010). While literary authors such as Tom Lanoye or Dimitri Verhulst occasionally flirt with Tussentaal to provide their characters with authenticity and couleur locale, the literary profession typically upholds Standard Dutch as its medium of expression. Moreover, official language planning instances such as the Nederlandse Taalunie 'Dutch Language Union' are explicitly hostile towards Tussentaal in any situation that calls for formal language. Finally, although the VRT allows some Tussentaal in popular series (again, for purposes of authenticity), the national media continue to combat Tussentaal in every other context (Vandenbussche 2010). 
The clearest indication of a changing attitude towards Tussentaal is the "defection" of a substantial proportion of the youngest generation of specialists, whereas most from the previous generation were ardent defenders of the integrationist ideology and, therefore, passionate combatants of Tussentaal, but

a number of other (mostly younger) specialists of Dutch in Flanders has turned the condemnation of Tussentaal into an object of study, advocating a less prejudiced attitude against a phenomenon which can be considered as the natural emergence of an informal colloquial variety in Flanders.

(De Caluwe 2009:9)

De Caluwe (2009, note 1) refers to De Caluwe 2002 and Jaspers 2001 in this respect. Zenner et al. (2008) also mention Van de Velde 1996.

It is unfortunate that there are no reliable speaker evaluation data yet to assess the degree of (implicit) communal acceptance of Tussentaal, and to access the SLI-if any-which constructs and negotiates its use. While it is obvious that the conservative ideology, which fuelled the importation and acceptance of the exoglossic norm, is rapidly crumbling, it is not clear whether a more liberal ideology is currently taking over in Flanders (as proposed for Netherlandic Dutch in Grondelaers \& Van Hout, to appear). If anything, there have been references to the "rebellious" overtones surrounding the dissemination and use of Tussentaal. Plevoets (2010:5) refers in this respect to the "hypocorrect" inclinations of the new economic elite that embraces Tussentaal:

While hypercorrection refers to an exaggerated polishing of language use which sounds rather artificial, hypocorrection refers to a sloppier and more careless language production [...]: While hypercorrection is characteristic for a middle class [...] which expresses its uncertain position between the lower and higher strata in an artificial realization of its language use, hypocorrection is the characteristic of the highest class [which manifests] a careless indifference with respect to the norms in order to profile its acquired position.

According to Van Gijsel et al. (2008:219ff.), commercials geared toward a younger market contain more Tussentaal in order to imitate the daily interactions of adolescent buyers and to gain their approval: "Apparently, Tussentaal has young, even somewhat rebellious, 
connotations, as opposed to the 'conformist' norm of the standard language."

Before we turn to our conclusions, a pivotal question remains to be answered, namely whether the present-day language situation is changing into a diaglossic configuration in Flanders, as we have suggested. While the absence of diachronic data precludes us from articulating a definitive answer, the available findings and descriptions strongly suggest a constellation that is already continuous, or is becoming continuous.

Let us, for the sake of the argument, depart-as Willemyns (2007) and Vandekerckhove (2009) do-from a configuration in which the dialects are losing ground and being replaced with a new colloquial Lvariety-Tussentaal - which also carries regional identity. This "lowest" variety of Tussentaal is characterized by regional variability (with a strong Brabantic influx), especially in the domains of morphosyntax and pronunciation. The highest variety between the (extant) dialects and the exoglossic standard that could reasonably be called Tussentaal is the Flemish-flavored Dutch spoken in animated cartoons such as Bee Movie (Dreamworks 2009). The variety heard there is not entirely colloquial because it is scripted, but it is produced with a sense of lively enactment by Flemish actors. While it is not clear whether these actors are expected to adhere to the VRT-norm-the fact that the je/jij-system is used instead of the ge/gij-paradigm typical for Tussentaal suggests that they are-the variety eventually produced falls ostensibly short of that norm. There are numerous Brabantic features present throughout the movie: in addition to the monophthongal rendering of diphthongs /ei/ and /ui/, some morphosyntactic features typical of Tussentaal appear, notably $h$-procope-oe instead of hoe 'how' - and recurrent $t$-apocope in the pronouns dat 'that' and wat 'what' (pronounced as $d a$ and $w a$, respectively), and the negative particle niet 'not' (pronounced as nie). In addition, typically Flemish words such as amaai (indicating surprise), effe 'just for a moment', and toeme 'damned' abound.

Crucially, this "Disney" variety of Tussentaal is not all that different from the "lower" colloquial variety. Interestingly, the readjustment of just one variable has profound consequences for the perceptual prestige of the variety evaluated. In Bee Movie, the sudden change from the je/jijto the $g e / g i j$-system in the speech of an unsympathetic character "pushes" the Tussentaal down the continuum toward the "lower" pole. Yet, it is obvious that the higher and lower varieties of Tussentaal are not com- 
partmentalized in the sense of Auer (2011) because it is not the case that "their features co-vary in two-sided co-occurrence restrictions" (p. 494). In other words, the realization of a lower Tussentaal variable does not imply the dialectal realization of all other lower Tussentaal variables as well (and vice versa). This analysis strongly endorses Plevoets et al.'s (2007) conclusion that Tussentaal is not a uniform language variety. We are justified, therefore, in assuming a continuous relation between the lower and intermediate strata in the present-day Belgian dialect-standard configuration.

Yet, what is the relationship between the lower/intermediate strata and the top layer(s)? Observe, to begin with, that Belgian Disney-Dutch is not all that different from Belgian VRT-Dutch: changing the informal diphthong, pronoun, and negative particle variable into their standard realizations would result in a variety that overlaps considerably with the highest standard. De Caluwe (2009:15) argues in this respect that too many descriptions ignore the "considerable overlap between Tussentaal and the standard:" The phonetic basis of Tussentaal is standard (see also Goossens 2000:7) - although a Tussentaal speaker's regional background is typically identifiable - and much of the lexicon and morphosyntax is identical. In addition, De Caluwe (2009:16) claims that the insistence on Tussentaal's status as a separate entity is a linguistic artifact: The average Flemish speaker does not recognize a specific variety as Tussentaal (thus, it is unlikely that Flemings deliberately opt for Tussentaal in formal situations, as Taeldeman 1993 claims). De Caluwe then goes on to suggest that young adults know what standard Dutch is because that is what they hear on television and read in the papers, although it is not their "native" variety:

For the absolute majority of young Flemish adults, the variety which is being called Tussentaal by linguists is the mother tongue, the language of daily interaction, the variety in which they text messages and chat on the internet. It is a variety they can use in the whole of Flanders, and which they hear in the media, not only in soap series but also increasingly in informal talk shows, interviews with politicians, game shows, reality shows, human-interest shows, and commercials. For 21st century young Flemish adults, so-called Tussentaal simply is the colloquial variety in Flanders.

(De Caluwe 2009:17; italics and emphasis in the original) 
De Caluwe subsequently suggests a continuum between formal and informal spoken Dutch in the form of a series of "switches"- standard vs. colloquial variants - which can be adjusted in function of the formality of the situation. Crucially, according to De Caluwe 2009:20, the use of standard and colloquial spoken Dutch no longer entails any substitution between discrete systems.

While De Caluwe's proposal is very much in the spirit of Willemyns (2007), the latter does not go as far because in his view, the standard does not merge with more colloquial varieties but is "pushed to the extreme formality side of the continuum" (Willemyns 2007:270). However, the question is which standard is implied here: the exoglossic spoken norm (VRT-Dutch) or the "light" version of the spoken norm, the Dutch as spoken by the Flemish teachers in the Teacher Corpus? The data necessitate different predictions for the two types.

In Auer's (2011:499) view, the competition between the exoglossic norm and a newly emerging endoglossic standard leads to a temporary bilingualism in the highest strata of society, that is, until the endoglossic standard is established. However, the establishment of such a standard is typically a long process, as the gradual decline of exoglossic Latin as a European standard and exoglossic Swedish as the Finnish standard demonstrate. Often, Auer goes on, bilingualism persists, as, for instance, English did in Ireland after the establishment of modern Standard Irish in the mid-20th century.

As far as the competition between endoglossic Tussentaal and exoglossic VRT-Dutch is concerned, however, Auer's expectation of "bilingualism" is improbable - so is the notion "diglossia" because there are almost no Flemish speakers who master both varieties. Tussentaal and VRT-Dutch are spoken by different people in different contexts, and while VRT-Dutch may carry prestige, it has little spontaneity or vitality: Much of what is broadcasted on radio and television is fully written out or scripted, and its uniformity is artificially controlled and conserved by the broadcasting authorities. While this VRT-norm has always been difficult to attain, fewer and fewer present-day Flemings make the effort to attain it, especially now, when the people in the public eyepoliticians, managers, media people-openly switch to Tussentaal, even on radio or television. De Caluwe (2009:21) is, therefore, probably right in his prediction that VRT-Dutch will be supplanted, or at least influenced, by the more colloquial varieties 
Yet, recall that the variety that actually represents informal spoken Belgian Standard Dutch - the teachers' speech in the Corpus of Spoken Dutch - is not a homogeneous variety either in production or in perception. While some speakers approximate the VRT-ideal, others manifest substandard features typical of Tussentaal. Given the latter, and in view of the fact that the youngest generation of all professional groups in the Corpus of Spoken Dutch is currently inclining toward Tussentaal (Plevoets 2010), it is safe to predict that any gap that may still exist between the "higher" intermediate varieties of (colloquial) Flemish (as illustrated in Disney Dutch) and the lower instantiations of teachers' Dutch will be closed shortly.

\section{Where Are We Heading?}

Figures 5 and 6 (below) diagram the 20th century standard-dialect configurations in Belgian and Netherlandic Dutch, respectively. It is obvious from these synchronic representations that the respective stratificational configurations of the national varieties of Dutch have much in common (in spite of very different pre-20th century histories). Both represent diaglossic structures because language change has dissolved (or is dissolving) the originally discrete strata into a continuous structure without identifiable intermediate varieties. Moreover, in both varieties the dialect basis has (almost) completely eroded. This is diagrammed using the broken line ellipses at the bottom of figures 5 and 6 . A linguistic commonality between Belgian and Netherlandic Dutch, which cannot be adequately diagrammed in these individual repre-sentations, is the written standard variety, represented by separate solid dots at the top of the Belgian and Netherlandic configurations.

The emergence of the diaglossic situation on both sides of the border, however, was brought about by very different factors. In Auer's terminology, the 20th century evolution in Netherlandic Dutch started out from a complete endoglossic bottom-up standardization (Type B) with a diglossic relation between the standard and the dialects. In the last decades of the 20th century, the demise of the dialects put pressure on the standard to stratify in order to index regional and social identity in the place of the disappearing vernaculars. The resulting downward relaxation of the norm is represented by the dotted downward arrow. While this downward relaxation has been uniformally qualified as de- or sub- 


\section{Grondelaers and Van Hout}

standardization, we do not believe that any substandardization outside the Dutch norm has taken place.

Written standard

(Virtual) spoken VRT-standard

"Teacher" Dutch

"Higher" Tussentaal

"Lower" Tussentaal

Regiolects
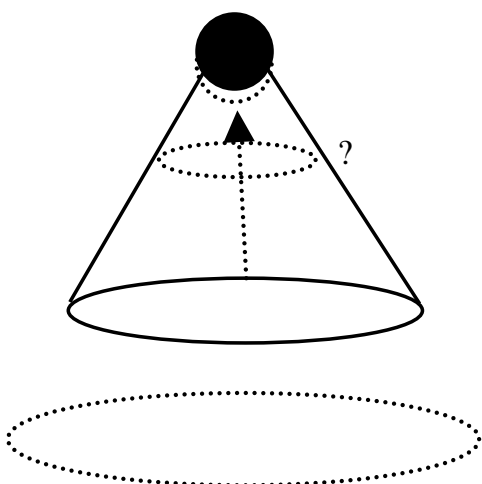

Figure 5. The current standard language situation in Flanders (dialect loss and endoglossic bottom-up standardization).

Written standard

Spoken standard, regionally and socially stratified
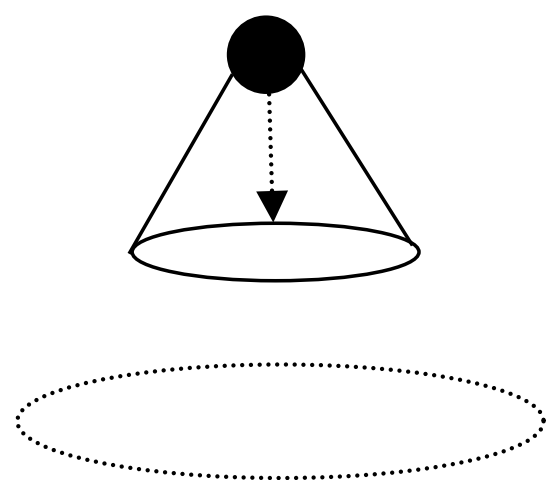

Figure 6. The current standard language situation in the Netherlands (dialect loss and top-down standard stratification).

Belgian Dutch, by contrast, started out as a Type Zero repertoire with a dialect base and an exoglossic standard variety imported from the Netherlands. While the written standard was successfully adopted by the Flemish public, the spoken variety-VRT Dutch-has always been considered an unattainable, virtual norm. In order to diagram this asymmetry, the solid dot at the top of the constellation in figure 5 represents 
the written standard, whereas the broken-line circle represents the virtual spoken norm. The partial overlap of the circles symbolizes the close relation between the written and the spoken exoglossic norm varieties (neither of which shows variation). In Flanders, the demise of the dialects engendered the emergence of a regional identity-carrying intermediate variety that subsequently began to standardize endoglossically (Type B, represented by the upward dotted line arrow). We have suggested that this development has closed, or is closing the gap between the colloquial varieties and the "real" spoken standard as represented by teachers' speech (Type C or D). The question-marked dotted line ellipsis in the Belgian representation symbolizes the possibility that the gap has not been closed completely yet.

At the end of this paper, we have one pivotal question left: where are we heading? With respect to the Flemish situation, we believe that the anticipated demise of VRT-Dutch could engender a new diglossia in Flanders, because the exoglossic standard is solely used for writing whereas the unsupported-unplanned and uncodified-endoglossic standard may never rise high enough in the configuration to occupy the current place of VRT-Dutch. It is difficult at this moment to predict this change with any degree of certainty, but the gradual abandoning of the VRT-norm and the absence of potential replacements are suggestive of Fairclough's (1992) more specific definition of destandardization:

Fairclough (1992) proposes that the democratisation process can lead to a value levelling that will secure access to public space for a wider range of speech varieties. Such a development would be equal to a radical weakening, and eventual abandonment of the "standard ideology" itself.

(Kristiansen 2009b:1-2)

All the evidence cited above seems to be compatible with this scenario. However, the perceptual data on teachers' Dutch are the most telling because they demonstrate that the highest stratum of spoken Belgian Dutch manifests a high degree of variability without there being a "best" variety: There is no accent which characterizes the best, the most prestigious, and the most beautiful Belgian Dutch. In the Netherlands, the Randstad accent is the only appropriate variety in this respect, and its norm exclusiveness typically correlates with high prestige and beauty. In Belgium, the Antwerp, Brabant, and East Flemish accents all enjoy a comparable prestige (although it seems more appropriate to say that these 
accents owe their prestige to the fact that the really peripheral accents (Limburg and West Flanders) are deemed so very nonprestigious). In the same vein, the Standard Language Ideology that negotiates and constructs Tussentaal-the variety that is rapidly becoming the new standard of Belgian Dutch-is not sustained by constructive "best language" perceptions (of excitement, enthusiasm, progress, etc.). Instead, it is informed by negative and rebellious perceptions hypocorrectly directed against the exoglossic standard. There is, in other words, no vital standard variety of Belgian Dutch, neither from the production, nor from the perception point of view.

It is at present unclear how this situation will evolve. Tussentaal may further standardize to take over the role of VRT-Dutch as the "best spoken language." Yet another possible scenario could be the "double norm" situation attested in Danish, where, according to Kristiansen (2001), a conservative standard is reserved for the schools and a modern standard for the media. In much the same way, VRT-Dutch could continue to play its conservative role as an "accentless" and therefore neutral medium for news and culture coverage, while Tussentaal (or a more standardized form of Tussentaal) becomes the more dynamic (media) variety, albeit without any pretence to being the best language.

The Netherlandic evolution, by contrast, appears to embody "the belief that there is, and should be, a 'best language', but the idea of what this 'best language' is, or sounds like, changes" (Kristiansen 2009b:2). At present, there are no indications that the Netherlands has relaxed its standard language ideal: There are simply more varieties (regional and social) which satisfy that ideal. All the available attitudinal evidence seems to point in this direction. All listeners who evaluated the speech samples in Grondelaers et al. 2010 find the Randstad accent the most beautiful variety of Dutch, and the most appropriate variety for formal interaction. Interestingly, while Limburg-accented speech is considered somewhat less beautiful, it is not downgraded for the purposes of formal interaction (when compared to the other nonprestigious accents, which receive very low norm ratings).

The listeners in Van Bezooijen 2001 likewise consider non-accented spoken Standard Dutch to be the most beautiful variety of Dutch, but especially younger listeners find Poldernederlands equally appropriate for formal interaction. The fact that the standard variety is dubbed the most beautiful, while other varieties are also deemed appropriate for 
formal communication suggests a standard language ideal that may be satisfied by different varieties. We have proposed that this public acceptance of variability in Netherlandic Dutch is proof of the stratification of the Netherlandic standard in order to carry regional and social identities. In this respect, the downward norm relaxation attested in this paper is not a form of standard demise-as purported by influential specialists such as Stroop (2010) or Van der Horst (2008)but a form of standard enrichment: While it becomes less general, the standard also becomes less sterile by acquiring social meanings and adapting to more diverse contexts of use.

\section{REFERENCES}

Adank, Patti, Roeland van Hout, \& Hans Van de Velde. 2007. An acoustic description of the vowels of Northern and Southern Standard Dutch II: Regional varieties. Journal of the Acoustical Society of America 121.11301141 .

Auer, Peter. 2005. Europe's sociolinguistic unity, or: A typology of European dialect/standard constellations. Perspectives on variation, ed. by Nicole Delbecque, Johan Van der Auwera, \& Dirk Geeraerts, 7-42. Berlin: Mouton de Gruyter.

Auer, Peter. 2011. Dialect vs. standard: A typology of scenarios in Europe. The languages and linguistics of Europe. A comprehensive guide, ed. by Bernd Kortmann \& Johan Van der Auwera. Berlin: De Gruyter.

Beheydt, Ludo. 2003. De moeizame weg van een standaardtaal. Waar gaat het Nederlands naartoe? Panorama van een taal, ed. by Jan Stroop, 152-163. Amsterdam: Bert Bakker.

Bennis, Hans. 2003. Hoeveel talen telt het Nederlands? Over taalvariatie en taalbeleid. Waar gaat het Nederlands naartoe? Panorama van een taal, ed. by Jan Stroop, 25-34. Amsterdam: Bert Bakker.

Bergen, Geertje van, Wessel Stoop, Jorig Vogels, \& Helen de Hoop. 2011. Leve Hun! Waarom hun nog steeds hun zeggen. Nederlandse Taalkunde 16. 2-29.

Bezooijen, Renée van. 2001. Poldernederlands. Hoe kijken vrouwen ertegen? Nederlandse Taalkunde 6. 257-271.

Cajot, José. 1999. Vlaanderens eeuwige weg naar een standaardtaal. Bedrijfsbeheer \& Taalbedrijf. Jubileumboek 30 jaar VLEKHO, 367-379. Brussel: VLEKHO.

Deumert, Ana, \& Wim Vandenbussche (eds.). 2003. Germanic standardizations: Past to present (Impact: Studies in Language and Society). Amsterdam: John Benjamins. 
De Caluwe, Johan. 2002. Tien stellingen over functie en status van tussentaal in Vlaanderen. Taalvariatie \& Taalbeleid. Bijdragen aan het taalbeleid in Nederland en Vlaanderen, ed. by Johan De Caluwe, Dirk Geeraerts, Sjaak Kroon, Virginie Mamadouh, Ronald Soetaert, Luc Top, \& Ton Vallen, 57-67. Antwerpen/Apeldoorn: Garant.

De Caluwe, Johan. 2009. Tussentaal wordt omgangstaal in Vlaanderen. Nederlandse Taalkunde 14. 8-25.

Elspass, Stephan, Nils Langer, Joachim Scharloth, \& Wim Vandenbussche (eds.). 2007. Germanic language histories “from below” (1700-2000). Berlin: Mouton de Gruyter.

Fairclough, Norman. 1992. Discourse and social change. Cambridge: Polity Press.

Geeraerts, Dirk. 1990. Het dialect en de dialectiek, de Verlichting en het Vlaams. Dietsche Warande \& Belfort 135. 432-441.

Geeraerts, Dirk. 1993. Postmoderne taalattitudes? Streven 60. 346-353.

Geeraerts, Dirk. 1999. De Vlaamse taalkloof. Over Taal 38. 30-34.

Geeraerts, Dirk. 2001a. Everyday language in the media. The case of Belgian Dutch soap series. Sprache im Alltag. Beiträge zu neuen Perspektiven in der Linguistik Herbert Ernst Wiegand zum 65. Geburtstag gewidmet, ed. by Matthias Kammerer, Klaus-Peter Konerding, Andrea Lehr, Angelika Storrer, Caja Thimm, \& Werner Wolski, 281-291. Berlin: Walter de Gruyter.

Geeraerts, Dirk. 2001b. Een zondagspak? Het Nederlands in Vlaanderen: Gedrag, beleid, attitudes. Ons Erfdeel 44. 337-344.

Geeraerts, Dirk. 2004. Gade gijlie nu allemaal zo klappen? De evolutie van het Nederlands in Vlaanderen. Reflector 5. 13-15.

Geeraerts, Dirk, \& Gert De Sutter. 2003. Ma wa zegdegij nu? Da kanekik nie verstaan zelle! Waar gaat het Nederlands naartoe? Panorama van een taal, ed. by Jan Stroop, 54-64. Amsterdam: Bert Bakker.

Geeraerts, Dirk, \& Stefan Grondelaers. 1997. Heeft taalpropaganda effect? Taal en Tongval Themanummer 10.94-112.

Geeraerts, Dirk, Stefan Grondelaers, \& Dirk Speelman. 1999. Convergentie en divergentie in de Nederlandse woordenschat. Een onderzoek naar kleding-en voetbaltermen. Amsterdam: Meertensinstituut.

Giddens, Anthony. 1991. Modernity and self-identity. Self and society in the Late Modern Age. Cambridge: Polity Press.

Gijsel, Sofie van, Dirk Speelman, \& Dirk Geeraerts. 2008. Style shifting in commercials. Journal of Pragmatics 40. 205-226.

Goossens, Jan. 2000. De toekomst van het Nederlands in Vlaanderen. Ons Erfdeel 43. 3-13. 
Grondelaers, Stefan. 2000. De distributie van niet-anaforisch er buiten de eerste zinsplaats. Sociolexicologische, functionele en psycholinguïstische aspecten van er's status als presentatief signaal. Leuven: K.U. Leuven dissertation.

Grondelaers, Stefan, Katrien Deygers, Hilde van Aken, Vicky van den Heede, \& Dirk Speelman. 2000. Het CONDIV-corpus geschreven Nederlands. Nederlandse Taalkunde 5. 356-363.

Grondelaers, Stefan, Dirk Speelman, \& Dirk Geeraerts. 2008. National variation in the use of $e r$ 'there'. Regional and diachronic constraints on cognitive explanations. Cognitive sociolinguistics: Language variation, cultural models, social systems, ed. by Gitte Kristiansen \& René Dirven, 153-204. Berlin: Mouton de Gruyter.

Grondelaers, Stefan, Hilde van Aken, Dirk Speelman, \& Dirk Geeraerts. 2001. Inhoudswoorden en preposities als standaardiseringsindicatoren. De diachrone en synchrone status van het Belgische Nederlands. Nederlandse Taalkunde 6. 179-202.

Grondelaers, Stefan, \& Roeland van Hout. 2010a. Is Standard Dutch with a regional accent standard or not? Evidence from native speakers' attitudes. Language Variation and Change 22. 1-19.

Grondelaers, Stefan, \& Roeland van Hout. 2010b. Do speech evaluation scales in a speaker evaluation experiment trigger conscious or unconscious attitudes? University of Pennsylvania Working Papers in Linguistics 16.2/12. Available at http://repository.upenn.edu/pwpl/vol16/iss2/12.

Grondelaers, Stefan, \& Roeland van Hout. To appear. The standard language situation in the Netherlands. Standard languages and language standards in a changing Europe, ed. by Nik Coupland \& Tore Kristiansen. Oslo: Novus Forlag.

Grondelaers, Stefan, Roeland van Hout, \& Dirk Speelman. 2009. The robustness and stability of accent attitudes in Netherlandic and Belgian Standard Dutch. Paper presented at the 5th International Conference on Language Variation in Europe, Copenhagen.

Grondelaers, Stefan, Roeland van Hout, \& Mieke Steegs. 2009. Do explicit social cues level perceptual differences between accents in Netherlandic Standard Dutch? Artikelen van de Zesde Anéla-Conferentie, ed. by Ad Backus, Merel Keijzer, Ineke Vedder, \& Bert Weltens, 112-121. Delft: Eburon.

Grondelaers, Stefan, Roeland van Hout, \& Mieke Steegs. 2010. Evaluating regional accent variation in Standard Dutch. Journal of Language and Social Psychology 29. 101-116.

Hendrickx, Ruud. 1998. Het Taalcharter, p. 2. Available at http://taal.vrt.be/ extra/taalcharter.pdf.

Hinskens, Frans. 2007. New types of non-standard Dutch. Standard, variation, and language change in Germanic languages, ed. by Christian Fandrych \& Reinier Salverda, 267-279. Tübingen: Gunter Narr Verlag. 
Horst, Joop van der. 2008. Het einde van de standaardtaal. Een wisseling van Europese taalcultuur. Amsterdam: Meulenhoff.

Hout, Roeland van. 2003. Hun zijn jongens. Ontstaan en verspreiding van het onderwerp 'hun'. Waar gaat het Nederlands naartoe? Panorama van een taal, ed. by Jan Stroop, 277-286. Amsterdam: Bert Bakker.

Hout, Roeland van. 2006. Onstuitbaar en onuitstaanbaar: de toekomst van een omstreden taalverandering. Wat iedereen van het Nederlands moet weten en waarom, ed. by Nicoline van der Sijs, Jan Stroop, \& Fred Weerman, 42-54. Amsterdam: Bert Bakker.

Hout, Roeland van, Georges De Schutter, Erika De Crom, Wendy Huinck, Hanne Kloots, \& Hans Van de Velde. 1999. De uitspraak van het StandaardNederlands. Variatie en varianten in Vlaanderen en Nederland. Artikelen van de derde sociolinguïstische conferentie, ed. by Erica Huls \& Bert Weltens, 183-196. Delft: Eburon.

Jacobi, Irene. 2008. On variation and change in diphthongs and long vowels of spoken Dutch. Nijmegen: Radboud University Nijmegen dissertation.

Jaspers, Jürgen. 2001. Het Vlaamse stigma. Over tussentaal en normativiteit. Taal en Tongval 53. 129-153.

Istendael, Geert van. 1989. Het Belgisch labyrint. Wakker worden in een ander land. Amsterdam: De Arbeiderspers.

Kloeke, Gesinus G. 1951. Gezag en norm bij het gebruik van Verzorgd Nederlands. Amsterdam: Meulenhoff.

Kristiansen, Tore. 2001. Two standards: One for the media and one for the school. Language Awareness 10.9-24.

Kristiansen, Tore. 2009a. The macro level social meaning of late modern Danish accents. Acta Linguistica Hafniensia 40. 167-192.

Kristiansen, Tore. 2009b. The nature and role of language standardization and standard languages in late modernity. Unpublished project proposal for SLICE-workshop.

Lambert, Wallace E., R. C. Hodgson, Robert C. Gardner, \& Samuel Fillenbaum. 1960. Evaluative reactions to spoken languages. Journal of Abnormal and Social Psychology 66. 44-51.

Mattheier, Klaus J. 1998. Über destandardisierung, Umstandardisierung und Standardisierung in modernen Europäischen Standardsprachen.

Standardisierung und Destandardisierung europäischer Nationalsprachen, ed.

by Klaus J. Mattheier \& Edgar Radtke, 1-9. Frankfurt: Peter Lang.

Milroy, James, \& Lesley Milroy. 1985. Authority in language. London:

Routledge \& Kegan Paul.

Penninckx, Willy, \& Paul Buyse. 1997. Correct taalgebruik. Kortrijk/Heule: UGA. 
Permentier, Ludo. 2003. Televisienederlands en Schoon Vlaams. Taalschrift, Tijdschrift over Taal en Taalbeleid. Available at http://taalschrift.org/ reportage/000458.html.

Plevoets, Koen. 2009. Verkavelingsvlaams als de voertaal van de verburgerlijking van Vlaanderen. Studies van de Belgische Kring voor Linguïstiek, vol. 4. Available at http://webh01.ua.ac.be/linguist/SBKL/ sbk12009/ple2009.pdf.

Plevoets, Koen, Dirk Speelman, \& Dirk Geeraerts. 2007. A corpus-based study of modern colloquial "Flemish." Elspass, Langer, Scharloth, \& Vandenbussche 2007, 179-188.

Schutter, Georges de. 1980. Norm en normgevoelens bij Nederlandstaligen in België. De Nieuwe Taalgids 73.93-109.

Silverstein, Michael. 1979. Language structure and linguistic ideology. The elements: A parasession on linguistic units and levels, ed. by Paul R. Clyne, William F. Hanks, \& Carol L. Hofbauer, 193-247. Chicago, IL: Chicago Linguistic Society.

Smakman, Dick. 2006. Standard Dutch in the Netherlands. A sociolinguistic and phonetic description. Utrecht: LOT Publishers.

Smakman, Dick, \& Renée van Bezooijen. 1997. Een verkenning van populaire ideeën over de standaardtaal van Nederland. Taal en Tongval, themanummer 10: Standaardisering in Noord en Zuid, 126-139.

Stroop, Jan. 1998. Poldernederlands; waardoor het ABN verdwijnt. Amsterdam: Bert Bakker.

Stroop, Jan. 2010. Hun hebben de taal verkwanseld. Over Poldernederlands, 'fout' Nederlands en ABN. Amsterdam: Athenaeum.

Taeldeman, Johan. 1993. Welk Nederlands voor de Vlamingen? Van sneeuwpoppen tot tasmuurtje. Aspecten van de Nederlandse taal-en literatuurstudie, ed. by Luc de Grauwe \& Jaak de Vos, 9-28. Gent, Belgium: Bond Gentse Germanisten.

Taeldeman, Johan. 2007. Het Vlaamse taallandschap verschraalt. De Standaard, 7 juli 2007.

Vandekerckhove, Reinhild. 2004. Waar zijn je, jij en jou(w) gebleven? Pronominale aanspreekvormen in het gesproken Nederlands van Vlamingen. Taeldeman, man van de taal, schatbewaarder van de taal, ed. by Johan De Caluwe, Georges De Schutter, Magda Devos, \& Jacques Van Keymeulen, 981-994. Gent: Academia Press.

Vandekerckhove, Reinhild. 2006. Chattaal, tienertaal en taalverandering: (sub)standaardiseringsprocessen in Vlaanderen. Handelingen van de Koninklijke Zuid-Nederlandse Maatschappij voor Letterkunde en Geschiedenis 59, ed. by Rita Beyers, 139-158. Brussels: Koninklijke ZuidNederlandse Maatschappij voor Letterkunde en Geschiedenis. 
Vandekerckhove, Reinhild. 2007. 'Tussentaal' as a source of change from below in Belgian Dutch. A case study of substandardization process in the chat language of Flemish teenagers. Elspass, Langer, Scharloth, \& Vandenbussche 2007, 189-203.

Vandekerckhove, Reinhild. 2009. Dialect loss and dialect vitality in Flanders. International Journal for the Sociology of Language 196. 73-97.

Vandenbussche, Wim. 2007. Shared standardization factors in the history of sixteen Germanic languages. Standard, Variation und Sprachwandel in germanischen Sprachen/Standard, variation and language change in Germanic Languages, ed. by Christian Fandrych \& Reinier Salverda, 25-36. Tübingen, Germany: Gunter Narr Verlag.

Vandenbussche, Wim. 2008. Het einde van de standaardtaal? Een controversieel boek van Joop van der Horst. Ons Erfdeel 51. 188-191.

Vandenbussche, Wim. 2010. Standardization through the media. The case of Dutch in Flanders. Variatio delectat. Empirische Evidenzen und theoretische Passungen sprachlicher variation (für Klaus J. Mattheier zum 65.

Geburtstach), ed. by Peter Gilles, Joachim Scharloth, \& Evelyn Ziegler 309322. Frankfurt am Main: Peter Lang.

Velde, Hans van de. 1996. Variatie en verandering in het gesproken StandaardNederlands (1935-1993). Nijmegen: K.U. Nijmegen dissertation.

Velde, Hans van de, \& Muriel Houtermans. 1999. Vlamingen en Nederlanders over de uitspraak van nieuwslezers. Artikelen van de Derde Sociolinguïstische Conferentie, ed. by Erica Huls \& Bert Weltens, 451-462. Delft: Eburon.

Velde, Hans van de, Mikhail Kissine, Evie Tops, Sander van der Harst, \& Roeland van Hout. 2010. Will Dutch become Flemish? Autonomous developments in Belgian Dutch. Multilingua 29. 385-416.

Velde, Hans van de, Roeland van Hout, \& Marinel Gerritsen. 1997. Watching Dutch change: A real time study of variation and change in Standard Dutch pronunciation. Journal of Sociolinguistics 1.361-391.

Willemyns, Roland. 1997. Dialektverlust im Niederländischen Sprachraum. Zeitschrift für Dialektologie und Linguistik 64. 129 -154.

Willemyns, Roland. 2003. Dutch. Germanic standardization: Past to present (Impact: Studies in language and society 18), ed. by Ana Deumert \& Wim Vandenbussche, 93-125. Amsterdam: John Benjamins.

Willemyns, Roland. 2005. Verkavelingsbrabants. Werkt het integratiemodel ook voor tussentalen? Neerlandica extra Muros 43. 27-40.

Willemyns, Roland. 2007. De-standardization in the Dutch language territory at large. Standard, variation and language change in Germanic languages, ed. by Christian Fandrych \& Reinier Salverda, 267-279. Tübingen: Gunter Narr. Woolard, Kathryn. 1998. Introduction: Language ideology as a field of enquiry. Language ideologies. Practice and theory, ed. by Bambi B. Schieffelin, 
Kathryn A. Woolard, \& Paul V. Kroskrity, 3-47. Oxford: Oxford University Press.

Zenner, Eline, Dirk Geeraerts, \& Dirk Speelman. 2009. Expeditie Tussentaal: leeftijd, identiteit, context in "Expeditie Robinson." Nederlandse Taalkunde 14. 26-44.

Stefan Grondelaers

Centre for Language Studies

Radboud University of Nijmegen

Postbus 9103

6500 Nijmegen

The Netherlands

[s.grondelaers@let.ru.nl]

Roeland van Hout

Centre for Language Studies

Radboud University of Nijmegen

Postbus 9103

6500 Nijmegen

The Netherlands

[r.vanhout@let.ru.nl] 